\title{
The Impact of College Graduates on Bahamian Society: With Emphasis on Graduates from The College of The Bahamas
}

\section{William J. Fielding Director of Planning ${ }^{1}$}

\section{ABSTRACT}

Society at large, both government and residents, invests in education, a process which is considered to reach its apex with a university qualification. Economically, education is typically seen to be both a private and public good, and so it is useful to determine the benefits to both the individual and society arising from this investment. This paper examines the economic contributions of university-educated Bahamians to society. Using information obtained from The College of The Bahamas and other official sources, the study demonstrates that having a populace with higher education has a beneficial impact upon the Bahamian economy.

\section{INTRODUCTION}

Politicians throughout the world make myriad promises to electorates with the objective that their agenda for the county will result in their being elected to government. A common promise made during elections is that of increased economic prosperity. Associated with this promise is that of greater educational opportunity, as it is appreciated that in today's society, unless one has the necessary educational qualifications one's work opportunities and income will be limited.

The inauguration of The College of The Bahamas was a manifestation of such political promises made at the time of Independence in 1973. At the opening of the College in 1975, the Prime Minister stated that the College would soon become a university; a promise which still remains unfilled. However, the government's commitment to transforming the
College to a university was more recently restated in 2012 (Progressive Liberal Party, 2012, p. 139). This apparent ambivalence, or at least caution, towards higher education in The Bahamas may reflect a lack of awareness of the contribution which those who have university-level qualifications make to Bahamian society. While there have been studies undertaken elsewhere to show the impact of higher education on society (Organization for Economic Cooperation and Development, 2012), no similar study appears to have been done for The Bahamas, although a positive impact has been assumed and articulated by Keva Bethel (1999).

This paper will use data from the Bahamas Department of Statistics, much of which were specially prepared at the request of the author, and from the College of The Bahamas to demonstrate, primarily in monetary terms, the

\footnotetext{
${ }^{1}$ William J. Fielding, Director of Planning, The College of The Bahamas, P.O. Box N-4912, Nassau, Bahamas.

Acknowledgments: The author thanks the Department of Statistics for providing the data for this study. E-mail: william.fielding@cob.edu.bs

APA reference: Fielding, W. J. (2014). The impact of college graduates on Bahamian society: With emphasis on graduates from The College of The Bahamas. The International Journal of Bahamian Studies, 20(2), V 1-11. https://doi.org/10.15362/ijbs.v20i2.209
}

(C) W.J. Fielding, 2014. Journal compilation @ The International Journal of Bahamian Studies, 2014 
value of higher education to the Bahamian economy. I attempt to determine whether the promises of politicians are justified. Is public expenditure on higher education justified? Should public expenditure on higher education be seen as a priority? Education can be considered both a public and private good, so therefore, I shall explore the public and private benefits of Bahamians having a college/university education.

\section{Funding the College of The Bahamas}

The College is funded in part by a government grant of around \$25 million dollars per annum. This represents only about half of the cost of educating students at the College in a given academic year as shown in Table 1. While this grant may appear to be a significant sum for a small country to spend on higher education, it represents only about $13 \%$ of the total amount spent by the Department of Education. As such, according to Altbach, Reisberg and Rumbley (2009) it is proportionately less than the amount spent on tertiary education in Barbados (30\%), Jamaica (20\%), United States $(26 \%)$ and Canada $(36 \%)$. The grant represented less than $1.3 \%$ of total government recurrent expenditure in 2012/13. Seen in this light, the investment by government does not seem large by international standards.

Table 1: Sources of funding to The College of The Bahamas

\begin{tabular}{lllllll}
\hline \multicolumn{1}{c}{ Funding Source: } & $2007 / 8$ & $2008 / 09$ & $2009 / 10$ & $2010 / 11$ & $2011 / 12$ & $\%$ of total \\
\hline Government grant & $\$ 26,760,395$ & $\$ 27,365,690$ & $\$ 24,719,753$ & $\$ 22,247,778$ & $\$ 24,719,753$ & $56 \%$ \\
Tuition and fees & $\$ 15,669,315$ & $\$ 15,005,140$ & $\$ 16,665,874$ & $\$ 16,349,191$ & $\$ 20,834,219$ & $37 \%$ \\
Other & $\$ 2,831,025$ & $\$ 2,899,199$ & $\$ 2,463,882$ & $\$ 4,369,588$ & $\$ 2,611,492$ & $7 \%$ \\
\hline Total & $\$ 45,260,735$ & $\$ 45,270,029$ & $\$ 43,849,509$ & $\$ 42,966,558$ & $\$ 48,165,464$ \\
\hline
\end{tabular}

The government grant is matched by funds obtained from various other sources to pay for students' education. Therefore, if education is seen as both a public and private good, the funding sources from both government and private sources reflect this in almost equal measure. The subvention per student has been about $\$ 5,100$ in recent years. The subvention to the College assists in making a higher education available to those who might otherwise be disenfranchised. As adults have indicated, their level of education attainment was largely determined by the family's income, and so assistance beyond the family finances is clearly necessary if people are to obtain the education required by today's labour force (Table 2). Households in which family income has had a positive impact on educational attainment are able to enhance the potential educational attainment of their children as compared to children from lower income households (Exact $\chi^{2}=99.74$, df $=32, \mathrm{n}=$ $412, \mathrm{p}<.001$; This relationship still holds even when the data are adjusted for sex effect of respondents, as indicated by a CochranMantel-Haenszel test for stratified tables).

\begin{tabular}{|c|c|c|c|c|c|c|}
\hline \multirow{2}{*}{$\begin{array}{l}\text { Educational attainment } \\
\text { of respondent }\end{array}$} & \multicolumn{5}{|c|}{ Perceived impact of family income on educational attainment } & \multirow{2}{*}{ Overall } \\
\hline & Very negative & $\begin{array}{c}\text { Somewhat } \\
\text { negative }\end{array}$ & No impact & Somewhat positive & Very positive & \\
\hline Lower secondary and below & $14.7 \%$ & $4.0 \%$ & $2.4 \%$ & $2.3 \%$ & $1.1 \%$ & $3.5 \%$ \\
\hline Upper secondary & $26.5 \%$ & $41.4 \%$ & $26.8 \%$ & $29.5 \%$ & $19.6 \%$ & $29.4 \%$ \\
\hline Post secondary certs & $20.6 \%$ & $18.2 \%$ & $17.1 \%$ & $15.9 \%$ & $10.9 \%$ & $15.9 \%$ \\
\hline Undergraduate degrees & $32.4 \%$ & $30.3 \%$ & $45.1 \%$ & $39.8 \%$ & $55.4 \%$ & $41.5 \%$ \\
\hline Graduate degrees & $5.9 \%$ & $6.1 \%$ & $8.5 \%$ & $12.5 \%$ & $13.0 \%$ & $9.6 \%$ \\
\hline Total & 34 & 99 & 82 & 88 & 92 & 395 \\
\hline
\end{tabular}

Source: Taylor \& Johnson (2012). 
What has been the College's contribution to educating the country?

Since the College opened, it has graduated over 12,000 students. In more recent years, it has focused on granting associate and baccalaureate degrees. Table 3 provides estimates that between 1990 and 2009 the majority of residents who obtained an associate degree did so from the College. During the same period, an increasing number of residents obtained baccalaureate degrees from the College.

Table 3: Estimated percentage of new degrees in the country conferred by The College of The Bahamas.

\begin{tabular}{lll}
\hline Period & Associate Degrees & Baccalaureate Degrees \\
\hline $1990-1999$ & $79.0 \%$ & $2.9 \%$ \\
$2000-2009$ & $63.8 \%$ & $14.8 \%$ \\
\hline
\end{tabular}

Note: Estimates based on changes in the number of degree holders in the previous decile period reported by the Census.

Between 2000 and 2009, the College of The Bahamas graduated almost 4,000 persons at the associate and baccalaureate levels. This represents a substantial proportion of those who had these qualifications in the country as seen in Table 4 below.

Table 4: Number of $\mathrm{COB}$ ) graduates, and the estimated contribution to the mass of higher educated persons by age group.

\begin{tabular}{lccccc} 
& & \multicolumn{2}{c}{ Age group* } & \multicolumn{2}{c}{ COB graduates as a percentage of: } \\
Degree & COB graduates (2000-2009) & $20-34$ & $20-44$ & $20-34$ age group & $20-44$ age group \\
\hline Associate & 2,149 & 5,352 & 9,475 & $40.2 \%$ & $22.7 \%$ \\
Baccalaureate & 1,718 & 7,161 & 13,119 & $24.0 \%$ & $13.1 \%$ \\
\hline
\end{tabular}

\section{The value added function of a College education}

The College of The Bahamas typically receives students who have the requisite passes in the Bahamas General Certificate of Secondary Education (BGCSE) examinations and graduates them at the associate or baccalaureate levels. Mean annual earnings of a person with BGCSEs is $\$ 22,425$ while that of a person with an associate degree is $\$ 31,609$, and that of a person with a baccalaureate degree is $\$ 45,866$ (Bahamas Department of Statistics, 2013a).

Table 5 illustrates that the 3,867 persons graduating between 2000 and 2009 from the College would have earned $\$ 86.7$ million per year, based upon their BGCSE qualifications. With their College qualification this group would have earned \$146.7 million. Therefore, the graduates" "value added" can be estimated to be about $\$ 60$ million per year. In other words, these graduates have $\$ 60$ million a year more to spend in the economy than they would have if they had not attended The College of The Bahamas.

Given that the government invested about \$25 million in the College in 2013, this represents a return of $140 \%$ on its investment. It should be noted that these estimated figures are based only on graduates with associate and baccaulaureate degrees from 2000-2009, so the yearly value added would be higher than this figure, as the College also produces graduates with certificates, diplomas and master degrees. It is clear from this conservative estimate that the College graduates generate more money than the government invests in the College per year. 
Table 5: Contribution of College of The Bahamas (COB) graduates to the economy per year

\begin{tabular}{|c|c|c|c|c|c|c|c|}
\hline \multirow{4}{*}{ Degree } & \multicolumn{6}{|c|}{ Total annual average income } & \multirow{4}{*}{$\begin{array}{l}\text { Annual } \\
\text { return on } \\
\text { investment }\end{array}$} \\
\hline & \multirow{3}{*}{$\begin{array}{l}\text { COB } \\
\text { graduates } \\
\text { (2000- } \\
2009)\end{array}$} & \multirow{3}{*}{$\begin{array}{l}\quad \text { School } \\
\text { BGCSE } \\
\text { (Anticipated } \\
\text { earnings with } \\
\text { only BGCSEs) }\end{array}$} & \multicolumn{2}{|c|}{ College } & \multirow{3}{*}{$\begin{array}{l}\text { COB value } \\
\text { added vs. } \\
\text { BGCSE }\end{array}$} & \multirow{3}{*}{$\begin{array}{l}\text { COB } 2013 \\
\text { Subvention }\end{array}$} & \\
\hline & & & Earnings & ith degree: & & & \\
\hline & & & Associate & Baccaulaureate & & & \\
\hline Associate & 2,149 & $\$ 48,191,325$ & $\$ 67,927,741$ & & $\$ 19,736,416$ & & \\
\hline Baccalaureate & 1,718 & $\$ 38,526,150$ & & $\$ 78,797,788$ & $\$ 40,271,638$ & & \\
\hline Total & 3,867 & $\$ 86,717,475$ & $\$ 67,927,741$ & $\$ 78,797,788$ & $\$ 60,008,054$ & $\$ 24,994,543$ & 1.40 \\
\hline
\end{tabular}

\section{Direct contribution of graduates to the economy}

Several recent reports have indicated that the most important barrier to doing business in The Bahamas is a lack of an educated workforce (World Bank \& International Finance Corporation, 2011). College and university graduates make a direct contribution to the economy through their labour skills. The various occupational groups require different skills, and unless there are people with the required skills in each occupation group, the economy and by extension the country will suffer. College and university graduates are to be found in those occupations that are more educationally based. It is clear from Table 6 that the cadre of college and university-educated persons play important roles in leadership and professional positions. This means that the country can supply its own demand for trained professionals, rather than turning to foreigners to supply the skills required by today's workforce.

Table 6: Employed persons by major occupational group and highest level of educational attainment. Census 2010.

\begin{tabular}{lllllllll}
\hline Major occupational group & None & Pre-school & Primary & Secondary & Post-sec & College & Other & Total \\
\hline Manager & $0.3 \%$ & $0.0 \%$ & $1.6 \%$ & $41.0 \%$ & $8.6 \%$ & $48.1 \%$ & $0.4 \%$ & 14,357 \\
Professionals & $0.1 \%$ & $0.0 \%$ & $0.4 \%$ & $11.9 \%$ & $3.9 \%$ & $83.1 \%$ & $0.7 \%$ & 16,667 \\
Technicians & $0.1 \%$ & $0.0 \%$ & $0.9 \%$ & $42.9 \%$ & $11.4 \%$ & $44.3 \%$ & $0.5 \%$ & 17,299 \\
Clerical & $0.1 \%$ & $0.1 \%$ & $0.8 \%$ & $59.1 \%$ & $10.0 \%$ & $29.8 \%$ & $0.2 \%$ & 14,820 \\
Service & $0.6 \%$ & $0.1 \%$ & $3.2 \%$ & $75.6 \%$ & $9.9 \%$ & $10.4 \%$ & $0.3 \%$ & 39,824 \\
Skilled & $4.7 \%$ & $0.1 \%$ & $10.3 \%$ & $76.5 \%$ & $3.5 \%$ & $3.9 \%$ & $1.0 \%$ & 2,732 \\
Craft & $1.4 \%$ & $0.0 \%$ & $4.7 \%$ & $70.8 \%$ & $15.3 \%$ & $7.2 \%$ & $0.5 \%$ & 19,073 \\
Plant & $0.6 \%$ & $0.1 \%$ & $6.0 \%$ & $78.7 \%$ & $8.4 \%$ & $5.7 \%$ & $0.5 \%$ & 6,665 \\
Elementary & $4.2 \%$ & $0.1 \%$ & $9.3 \%$ & $77.1 \%$ & $5.0 \%$ & $3.8 \%$ & $0.6 \%$ & 23,068 \\
\hline
\end{tabular}

\section{Indirect contribution of graduates to the economy}

In common with studies from elsewhere, for example the United States (Cunningham, 2006), college graduates in The Bahamas contribute a number of far-ranging benefits to society. In 2010 , only $4.6 \%$ of those who had a university education were unemployed, compared to $15.4 \%$ of those who had a secondary education (Bahamas Department of Statistics, 2011). This suggests that many of those educated to the secondary level do not have the skills to support themselves, and so they cannot contribute economically to society. The value of incomes lost to society through unemployment can be estimated at between \$330-\$347 million for those with secondary school education and between \$56.4-\$81.9 million in the case of those with a college or university education. Given that the unemployed cannot consume goods and services at a similar rate as the employed, the 
government revenue base is subsequently reduced and this has implications for its budget and expenditure. In this regard, to educate more people beyond high school is advantageous to both government and society.

\section{Hospital Care}

Some $71.6 \%$ of college or university educated residents have health insurance, compared to $42.7 \%$ of those with secondary school education $^{2}$. The implication of this is that government does not need to provide health cover for college or university graduates to the same extent as residents with only a high school education. What is the potential benefit to government of this? In 2012-2013, the government budgeted $\$ 199,093,306$ for the Public Hospital Authority (Bahamas Ministry of Finance, 2012). Assuming that this allocation is to provide hospital services for the 169,060 people who do not have health insurance, it means that the Public Hospital Authority spends $\$ 1,177.65$ per person. This figure represents the money per person which government does not need to spend on those persons who have health insurance. Consequently, the college and university graduates with insurance save the government over $\$ 44$ million per year in medical costs. Or, putting it another way, the cost to government of proving hospital care to a college or university graduate is $\$ 335.49$ per person compared with $\$ 681.45$ for a person with secondary school education. In fact the savings are probably higher, as the savings through the use of private doctors' clinics are not included in these calculations. It is clear that the ability of college and university graduates to provide their own health cover is of major importance to the government purse.

The practicalities of health differences between residents with different educational attainment are exemplified by residents with a

\footnotetext{
${ }^{2}$ Special table from the 2010 Census.
}

college or university education being less likely to be obese than those with a high school education, $23.0 \%$ vs. $36.3 \%$ (Brathwaite, Brathwaite \& Taylor, 2011). According to a study in the United States the cost of treating an obese person is similar to the cost of treating a smoker (Thompson, Edelsberg, Colditz, Bird \& Oster, 1999). The Household Expenditure Survey $2013^{3}$ (Bahamas Department of Statistics, 2015) demonstrates that heads of household with a college or university education ate more healthily that those with only a high school education. For example, $71.1 \%$ of those with college or university education ate vegetables the previous day compared to $57.5 \%$ with high school education; $52.1 \%$ of those with college or university education drank fruit juice the previous day, compared to $43.3 \%$ of those with high school education; and $30.7 \%$ of those with college or university education drank fruit-flavoured drinks (e.g. Kool-Aid) the previous day compared to $42.3 \%$ with high school education So again, there are major advantages to society in increasing the level of education in the community.

\section{Expenditure on education 4}

Data from the 2001 Bahamas Living Conditions Survey (2004) show that households headed by college or university graduates rely less on public services than households headed by persons with a high school education. Only $13 \%$ of homes headed by persons with higher education used government schools, as opposed to $39 \%$ of those with a high school education. Again, the homes headed by a college or university graduate save government money by reducing the demand for government services. In the case of education, the cost to government was $\$ 201,770,380$ in 2012/13 (Bahamas Ministry

\footnotetext{
${ }^{3}$ Special table from the Household Expenditure Survey, 2013.

${ }^{4}$ Special table from the Bahamas Living Conditions Survey, 2001.
} 
of Finance, 2012). Assuming that 32\% of households use government schools, this works out at $\$ 6,136.00$ per household. Therefore, households headed by college or university educated persons save the government around $\$ 48$ million per year. Again, this saving per year to government expenditure represents far more than the yearly subvention to the College.

Due to their higher incomes, homes headed by college or university graduates are able to invest more in the education of their children, not only when using private schools but also public schools, Table 7. The differential in money spent on items such as books and supplies is marked between the two types of household. However, in the public school system, graduate-headed households still spend more on extra lessons that those headed by those with only a high school education. It is apparent that children of those from homes headed by a college or university graduate can be expected to have a more privileged or a more advantaged education as a result of their home circumstances. Clearly this has potential long-term consequences for the country as it attempts to increase the level of education of the population.

Table 7: Those with at least one person attending school, Average Household Expenditure per year (\$) on selected items

High School headed household

College / University headed household

All Households

Those with at least one person attending public school

\begin{tabular}{|c|c|c|c|}
\hline School tuition and fees & $\$ 60$ & $\$ 144$ & $\$ 56$ \\
\hline Extra classes & $\$ 20$ & $\$ 44$ & $\$ 18$ \\
\hline Books & $\$ 137$ & $\$ 158$ & $\$ 144$ \\
\hline \multicolumn{4}{|c|}{ Those with at least one person attending private school } \\
\hline School tuition and fees & $\$ 2,013$ & $\$ 4,118$ & $\$ 2,576$ \\
\hline Extra classes & $\$ 32$ & $\$ 328$ & $\$ 115$ \\
\hline Books & $\$ 171$ & $\$ 249$ & $\$ 195$ \\
\hline
\end{tabular}

Source: Bahamas conditions of living survey, 2001

\section{Crime and education}

Crime in The Bahamas is not so much fuelled by poverty but by the perceived need to increase earnings so that lifestyles can be enhanced (Stevenson, 2012). Stevenson's study reveals that only $6.4 \%$ of inmates at HM Prison Fox Hill had a college education. Given that overall, university educated persons account for $19.5 \%$ of the population aged 15 and over not attending school, it may be argued that persons with higher education are less likely to be criminals. With crime being a major concern of society and politicians, higher education can be seen as a useful means of reducing criminality (Lochner \& Moretti, 2003)

In 2012/13 the government estimated the cost of running the prison service at $\$ 23,036,978$
(Bahamas Ministry of Finance, 2012). In 2012, there were about 1,550 inmates at HM Prison Fox Hill (Prison Numbers Swell, 2012). This suggests that it costs $\$ 14,863$ per annum to house an inmate. The cost to society of confining inmates (incarceration and lost income) can be estimated at between \$4.6$\$ 6.1$ million per year for those with a college or university degree and between $\$ 50.5-\$ 52.0$ million per year for those with a high school education.

\section{Domestic violence}

It is difficult to assess the full cost of domestic violence in any society (National Center for Injury Prevention and Control, 2003); however, it is clear that the costs (financial and social) are not negligible. Further, in a county with a high incidence of rape (U.N. 
Office on Drugs and Crime \& World Bank, 2007) the relative cost of violence may be even higher in The Bahamas than elsewhere. In the absence of an offender's registry, we can only state that as domestic violence is more likely to occur in poorer households (Carroll, Fielding, Brennen, \& Hutcheson, 2011) and so by association, where residents would not have higher education, those with higher education will contribute less to the cost of domestic violence than those who do not have higher education.

\section{Creating a culture of education}

Richer homes (i.e. those of college graduates) are more likely to rear children who obtain a post-secondary qualification (Table 8). Consequently, the sooner, and the larger the number of people who can be educated beyond high school, the more rapidly the country can expect that future generations will be educated beyond high school. This process is essential if The Bahamas is to have a sufficiently large pool of labour with adequate skills to advance economic activity. Therefore, the future success of the country is dependent upon the success of higher education today.

\begin{tabular}{|c|c|}
\hline Household Expenditure Quintile & $\%$ of not in school \\
\hline 1 (Lowest) & $2.0 \%$ \\
\hline 2 & $4.1 \%$ \\
\hline 3 & $0.4 \%$ \\
\hline 4 & $12.5 \%$ \\
\hline 5 (Highest) & $23.0 \%$ \\
\hline
\end{tabular}

\section{Creating a culture of gender equality}

Despite the inequality faced by women in the region (Seguino, 2003), The Bahamas has a positive reputation in gender equality with one of the better gender inequality indexes (United Nations Development Programme, 2011, p. 139). This occurs despite the workplace still offering higher rewards to males than females.
Education helps in removing some of the inequalities that exist between males and females in the workplace. As shown in Table 9, females need higher levels of education than males in order to maximise their earnings. While the graduation ratio in favour of females at The College is sometimes considered a cause for concern (Brennen, 2003), a College education is an important means by which females can boost their earnings. Without the opportunity to get a higher level of education, females would face disadvantages to an even greater degree than they now do. This potential economic hardship is demonstrated by the fact that female-headed households in which children live have to survive on lower incomes than equivalent households headed by males, $19.4 \%$ of households headed by males have an income of $\$ 20,000$ or less compared to $34.8 \%$ of female-headed households. Consequently, higher education is an important means by which women can distance themselves from economic adversity.

\begin{tabular}{lll}
\multicolumn{3}{c}{ Table 9: Average personal income of employed persons } \\
\hline Highest qualification & Male & Female \\
\hline "O" levels & $\$ 26,346$ & $\$ 19,340$ \\
Associate's Degree & $\$ 38,295$ & $\$ 28,225$ \\
Baccalaureate degree & $\$ 61,170$ & $\$ 36,531$ \\
Master's degree & $\$ 73,806$ & $\$ 47,180$ \\
\hline All qualifications & $\$ 29,471$ & $\$ 22,611$ \\
\hline
\end{tabular}

\section{Creating a more stable society}

Marriage is generally seen to be a stabilizing structure in society. It is commonly accepted that there are advantages to children being reared in homes where the parents are in a stable relationship (Parke, 2003). Residents with college or university education are more likely to be married than heads of households with a high school education. This is the case for both males and females. Therefore, it can be expected that there are complex, if illdefined, social advantages to the nation resulting from higher education and its association with formal household units. 
According to the 2010 Census data, $31 \%$ of those with a high school education were currently married compared to $49 \%$ of college and university graduates (Bahamas Department of Statistics, 2012).

\section{Private benefits of higher education}

In addition to the public benefits of higher education, there are also private benefits which, while most obviously benefitting the individual, also have wider implications for society.

As noted above, college and university graduates earn more than those with a secondary school education. Not only is it the goal of many people to own their dwelling (Rodgers, 2013) but there are also social benefits to home ownership (Rossi \& Weber, 1996). Households headed by college or university graduates are less likely to reside in rented accommodation than households that are headed by persons with secondary school education, $30.0 \%$ vs. $39.0 \%$ (Bahamas Department of Statistics, 2012). Therefore, a college or university education is an important factor in helping people meet the goal of home ownership. Living in one's own home provides stability to household units that rental accommodation may not. Further, it represents a real buy-in to the community in which those householders live and so further advantages can be expected to accrue to society (Coulson, 2002).

For those heads of households who reported paying rent or a mortgage, the median cost, $\$ 890$, was higher for college or university educated heads of household than for those heads who had a secondary school education, \$586 (Bahamas Department of Statistics, 2012). The higher costs paid by college or university educated heads of households reflects the nature of the accommodation. While the majority of households headed by either persons with a secondary or college or university education had concrete as the material for the outer walls, $13.8 \%$ of homes headed by those with a secondary school education had outer walls made of wood, as compared to $3.7 \%$ of homes headed by those with college or university education. This indicates that dwellings occupied by household heads with college or university education are different to those occupied by heads with a secondary school education. Again when household heads had a college or university education, they lived in newer homes $(28.1 \%$ built before 1980) than when the household was headed by persons with secondary education (34.2\% built before 1980). So not only are the dwellings of those with a college or university education newer, but they are also larger than the dwellings of those headed by those with a secondary school education, typically having one more bedroom (Bahamas Department of Statistics, 2012). Incidental expenditure on furnishings, maintenance etc. point to additional economic activity as a result of university or college educated householders living in larger dwellings. The ability to occupy larger and newer dwellings indicates the important contribution of college or university graduates to the building sector of the economy.

Households headed by those with a college or university education feature more motor vehicles than those headed by persons with a secondary school education (Bahamas Department of Statistics, 2012). This makes the occupants of these homes more mobile, and more likely to consume items that are taxed by government and so adding to government revenues. In the case of motor vehicles, college and university educated members of society will generate proportionately more technical jobs than those with a secondary school education through their demand for services and repairs.

Modern society is technologically driven; one feature of this is access to the Internet. College and university graduates are more 
likely to have access to the Internet than those with a secondary school education. Many jobs involve some use of computer-related technology, and communication is, in many instances, by e-mail or text. The figures in
Table 10 show not only differences of Internet access by level of educational attainment, but also notable differences between the sexes when educated to a secondary school level.

Table 10: Internet access by highest educational attainment and sex, Census 2010

\begin{tabular}{lccccc} 
& & Secondary school & & \multicolumn{2}{c}{ College/university } \\
& Male & Female & Total & Male & Female \\
\hline Access to Internet & $59.9 \%$ & $64.1 \%$ & $62.0 \%$ & $92.0 \%$ & $93.7 \%$ \\
\hline Total & 88,101 & 86,616 & 174,717 & 19,498 & 32,863 \\
\hline
\end{tabular}

\section{Conclusion}

The Bahamas has been successful in educating its population as far as high school (Taylor, Gibson, \& Fielding, 2013). However, in today's competitive economic environment this achievement is not sufficient to propel the economic development of the country. Businesses need more highly-qualified workers than the high school system is now producing. More people need to be engaged in post-high school programmes. One way of achieving this is to provide accessibility to a quality college or university education in the country. The need for locally-funded higher education goes beyond the teaching function of the higher education institution; the benefits of university and college graduates to the country outweigh the cost of educating them to a tertiary level. These graduates become the motor that will generate more graduates to sustain the future growth of the economy. Their higher consumption of goods and services provided by the private sector in turn creates jobs and wealth for the wider economy. At the same time, college and university educated headed households are proportionately less reliant on public services than those headed by persons with a secondary school education, and so are less of a burden on the government purse. It is apparent that public expenditure on higher education can be justified as an area of priority as it accrues benefits far beyond the initial government investment. Consequently, it can be appreciated that the well-being of society is enhanced by having a populace with a college or university education.

\section{REFERENCES}

Altbach, P. G., Reisberg, L., \& Rumbley, L. E. (2009). Trends in global higher education: Tracking an academic revolution. Paris: UNESCO. Retrieved from http://atepie.cep.edu.rs/public/Altbach,_Rei sberg,_Rumbley_Tracking_an_Academic_ Revolution,_UNESCO_2009.pdf

Bahamas Department of Statistics. (2004). The Bahamas living conditions survey,
2001. Nassau, Bahamas: Author.

Bahamas Department of Statistics. (2011). Labour force and household income survey. Nassau, Bahamas: Author. Retrieved from http://statistics.bahamas.gov.bs/download/0 86361700.pdf

Bahamas Department of Statistics. (2012). 2010 Census of population and housing. Nassau, Bahamas: Author. Retrieved from http://statistics.bahamas.gov.bs/download/0 


\section{0.pdf}

Bahamas Ministry of Finance. (2012).

Estimates of expenditure on revenue account, 2012/13. Retrieved from http://www.bahamas.gov.bs/wps/wcm/conn ect/ca15826e-824d-4109-bbf4dc68436a3c5b/FY2012+Recurrent+Expen diture+Estimates+Details+20120529.pdf? MOD=AJPERES

Bethel, K. (1999). Educational reform in The Bahamas. Retrieved from http://www.wethepeoplebahamas.org/User Files/HTMLEditor/EDUCATIONAL REFORM IN THE BAHAMAS by keva bethel.pdf

Brathwaite, N., Brathwaite, A., \& Taylor, M. (2011). The socio-economic determinants of obesity in adults in the Bahamas. West Indian Medical Journal, 60(4), 434-441.

Brennen, B. H. (2003, November 20). Gender issues in tertiary education. Paper presented at the Association of Tertiary Education Annual Conference, Nassau, Bahamas. Retrieved from http://www.soencouragement.org/genderiss ues-in-higher-education.htm

Carroll, M., Fielding, W. J., Brennen, S., \& Hutcheson, S. (2011, November 5). Rearing violence in Bahamian homes. Paper presented at the Violence Symposium, College of the Bahamas. Retrieved from http://www.cob.edu.bs/Research/ViolenceS ymposium/ViolenceSymposium2011_Viole nceinHomes.pdf

Coulson, N. E. (2002). Housing policy and the social benefits of homeownership. Business Review, 2, 7-16.

Cunningham, A. (2006). The broader societal benefits of higher education. Washington, DC: Solutions for our Future. Retrieved from http://english.highline.edu/developmental/B
roader\%20Social\%20Benefits.pdf

Lochner, L., \& Moretti, E. (2003). The effect of education on crime: Evidence from prison inmates, arrests, and self-reports. Retrieved from http://files.eric.ed.gov/fulltext/ED463346.p df

National Center for Injury Prevention and Control. (2003). Costs of intimate partner violence against women in the United States. Atlanta, GA: Centers for Disease Control and Prevention. Retrieved from http://www.bvsde.paho.org/bvsacd/cd57/in timate.pdf

Organisation for Economic Cooperation and Development. (2012). What are the returns on higher education for individuals and countries? Education Indicators in Focus, 6. doi:10.1787/5k961169d8tg-en

Parke, M. (2003). Are married parents really better for children?: What research says about the effects of family structure on child well-being. Washington, DC: Center for Law and Social Policy. Retrieved from http://files.eric.ed.gov/fulltext/ED476114.p df

Progressive Liberal Party (Bahamas). (2012). A charter for governance. Nassau, Bahamas: Author. Retrieved from http://myplp.org/issues/charter/

Prison numbers swell (2012, May 25). The Bahamas Journal. Retrieved from http://jonesbahamas.com/prison-numbersswell/

Rodgers, K. J. (2013). The Bahamian dream. Nassau, Bahamas: Media Enterprises.

Rossi, P. H., \& Weber, E. (1996). The social benefits of homeownership: Empirical evidence from national surveys. Housing Policy Debate, 7(1), 1-35. Retrieved from http://content.knowledgeplex.org/kp2/img/ cache/documents/1374.pdf 
Seguino, S. (2003). Why are women in the Caribbean so much more likely than men to be unemployed? Social \& Economic Studies, 52(4), 83-120.

Stevenson, M. (2012, September 18). Economic discourse and criminality in The Bahamas. Paper presented at the Criminality Colloquium, College of The Bahamas.

Taylor, M. C., Gibson, J., \& Fielding, W. J. (2013, June 12). The role of education in national development: The case of an independent Bahamas. Paper presented at The Bahamas at Forty Colloquium, College of The Bahamas.

Taylor, M. C. \& Johnson, P. (2012). [Family factors and educational attainment]. Unpublished raw data.

Thompson, D., Edelsberg, J., Colditz, G. A., Bird, A. P., \& Oster, G. (1999). Lifetime health and economic consequences of obesity. Archives of Internal Medicine, 159(18), 2177-2183. http://dx.doi.org/10.1001/archinte.159.18.2 177

United Nations Development Programme. (2011). Human development report 2011. New York, NY: Author. Retrieved from http://hdr.undp.org/sites/default/files/report s/271/hdr_2011_en_complete.pdf

U.N. Office on Drugs and Crime, \& World Bank Latin America and the Caribbean Region. (2007). Crime, violence, and development: trends, costs, and policy options in the Caribbean. New York, NY: Author. Retrieved fromhttp://www.unodc.org/pdf/research/Cr _and_Vio_Car_E.pdf.

World Bank, \& International Finance Corporation. (2011). The Bahamas country profile 2010. Washington, DC: Author. Retrieved from http://wwwwds.worldbank.org/external/default/WDSC
ontentServer/WDSP/IB/2014/11/11/00047

0435_20141111143411/Rendered/PDF/92 2960WP0Box380PUBLIC00Bahamas0201 $0 . p d f$

http://microdata.worldbank.org/index.php/c atalog/864 